\title{
Protocol for tambaqui production based on stocking density and sex ${ }^{1}$ Protocolo para produção de tambaqui baseado na densidade de estocagem e sexo
}
Raquel Cavadas Tavares Mesquita ${ }^{2}$; Juliana Antunes Galvão ${ }^{3}$, Luciana Kimie Savay- da-Silva $^{4}$, Lidiane Raquel Eloy ${ }^{5}$, Leandro Cesar de Godoy ${ }^{6}$ and Danilo Pedro Streit $\mathbf{J r}^{7}$.

Resumo: O domínio de qualquer pacote-tecnológico zootécnico passa pelo conhecimento profundo da espécie objeto. Características reprodutivas, de crescimento, de comportamento e composição centesimal são algumas das principais questões a serem desvendadas para que a produção de qualquer espécie seja viável. O presente trabalho lança luz sobre as características pouco dominadas na produção da espécie nativa de maior interesse econômico, o tambaqui. E objetiva estudar a interferência do sexo e da intensidade do sistema de cultivo nos atributos de composição centesimal e rendimento de filé na fase de abate. Juvenis de tambaqui ( $75 \mathrm{~g}$, em média) foram cultivados em tanques escavados por dez meses, em duas densidades diferentes de sistemas de produção (quatro toneladas por hectare e seis toneladas por hectare). Cada animal foi considerado uma unidade amostral, totalizando 164 repetições (77 machos e 87 fêmeas). As análises realizadas para determinação da composição centesimal foram: Umidade e Lipídeos Totais; Proteína Bruta e Cinza. E as medidas foram: comprimento total, lombo, cabeça, largura, peso inteiro, peso de filé, peso residual (peso do animal inteiro menos peso do filé), peso de cabeça e rendimento de filé (peso do filé dividido pelo peso do animal inteiro). Para responder se, para tambaqui, existe diferença entre os diferentes adensamentos de cultivo e entre os sexos para as características de interesse comercial de tal espécie.

\footnotetext{
Palavra-chave: Colossoma macropomum, adensamento, cultivo monossexo, centesimal, zootécnico.
}

\begin{abstract}
The effective use to zootechnical technique involves a thorough knowledge of the target species. Reproductive characteristics, like growth, behavior and centesimal composition, are some of the main issues for the production the species to be viable in all aspects. This study sheds light on production features of tambaqui, a native species of greater economic interest in Brazil, that are little understood. We investigated the influence of sex and stocking density of rearing systems on centesimal composition and fillet yield at slaughter. Juveniles of tambaqui (75 g, on average) were grown in dug ponds for 10 months in two different stocking densities of production systems (4 and 6 tons per ha). Each animal was considered a sampling unit, totaling 164 repetitions (77 males and 87 females). The analysis to determine the centesimal composition were moisture, total lipids, crude protein and ash. The measurements undertaken were total length, loin, head, width, full weight, fillet weight, residual weight (weight of the whole animal minus fillet weight), fillet weight and yield (fillet weight divided by the weight of the whole animal). The aim was to investigate for differences in features of commercial interest between different stocking densities and sexes. The results showed differences between sexes and stocking densities, which requires identification of the most interesting features for the market for later adoption of rearing systems of monosex populations and stocking densities in fish farming.
\end{abstract}


Mesquita et al., Revista Brasileira de Higiene e Sanidade Animal (v.12, n.2) p. 146 -155 abr - jun (2018)

Keyword: Colossoma macropomum, stocking density, monosex rearing, centesimal, zootechnical index.

Corresponding author: quelmesquita@gmail.com

Recebido em 10.03.2018. Aceito em 30.06.2018

http://dx.doi.org/10.5935/1981-2965.20180014

1This work is part of the dissertation of the Graduate Program of Animal Science at the Universidade Federal do Rio Grande do Sul (UFRGS) and co-advisory of the Department of Agroindustry, Food and Nutrition at Luiz de Queiroz College of Agriculture (ESALQ - USP)

${ }^{2}$ Veterinarian and Ph.D. from UFRGS - quelmesquita@gmail.com;

${ }^{3} \mathrm{Ph} . \mathrm{D}$. and researchers from ESALQ - jugalvaousp@ gmail.com;

${ }^{4} \mathrm{Ph} . \mathrm{D}$. from ESALQ and professor doctor at UFMT - lukimie@ gmail.com;

${ }^{5} \mathrm{Ph} . D$. from UFRGS - lidianeloy@ hotmail.com;

${ }^{6} \mathrm{Ph} . D$. and professor doctor at UFRGS - leandro.godoy@ufrgs.br;

${ }^{7}$ Ph.D. from UEL and professor doctor at UFRGS - danilo.streit@ ufrgs.br

\section{Introduction}

To maximize zootechnical production of any species requires knowledge of reproduction and sexual features. There is difference of growth rate between sexes in different fish species (Ramos, 2016). Studies show that several factors influence fillet yield, namely the rearing system and sex. Thus, rearing systems of monosex populations of some fish species have been used to maximize yield and avoid uneven growth of batches (Borges, 2015; Brito, 2016).

Market requirements and growing demand for fish products with quality and standards have led fish production to an increasingly intensive system. However, the knowledge of morphophysiological, biological and centesimal features of the target species is required to increase fish production.
Tambaqui

(Colossoma macropomum) is the native species of great interest in the Brazilian market (Barçante \& Sousa, 2015) and the development of protocols to maximize gains during the growing phase is essential to make the product competitive in the market. Native to the Amazon basin, tambaqui is a round fish with high commercial value to the Brazilian market. Slaughter occurs at $2 \mathrm{~kg}$ of live weight at 10 months of rearing. Tambaqui presents dimorphism between males and females, the females grow faster than males after sexual maturity (Villacorta-Correa, 1999). However, there is no information on slaughter weight of tambaqui showing differences of fillet yields or centesimal features in monosex populations reared in intensive systems.

At slaughter, the product needs to have a standardized size for greater 
efficiency of the process; thus, the knowledge about the species characteristics is crucial to consolidate the production chain of native species. Similarly, the study on the chemical composition of fish provides subsides to the fields of nutrition and technology, helping in the use of the fish. Similar to morphology that can be dependent on sex, centesimal features can also vary between males and females.

This study investigates the influence of sex and stocking density of rearing systems on centesimal composition and fillet yield at slaughter of tambaqui. The search for information on the need to rear monosex populations of tambaqui makes this study pioneer to consolidate the technological procedures that have been developed in Brazil for this specie.

\section{Material and Methods}

Juveniles of tambaqui (75 g, on average) were grown in dug ponds for 10 months, in two different stocking densities of production systems (4 and 6 tons per ha). Individuals were trawled randomly, transported in thermal boxes, numbed (hypothermia) and slaughtered at a local slaughterhouse (under Municipal Inspection System - SIM) in compliance with the Standard Operating Procedure of the Agro-Industry. The fishs were identified to allow tracking throughout the process, according to procedures in Figure 1.

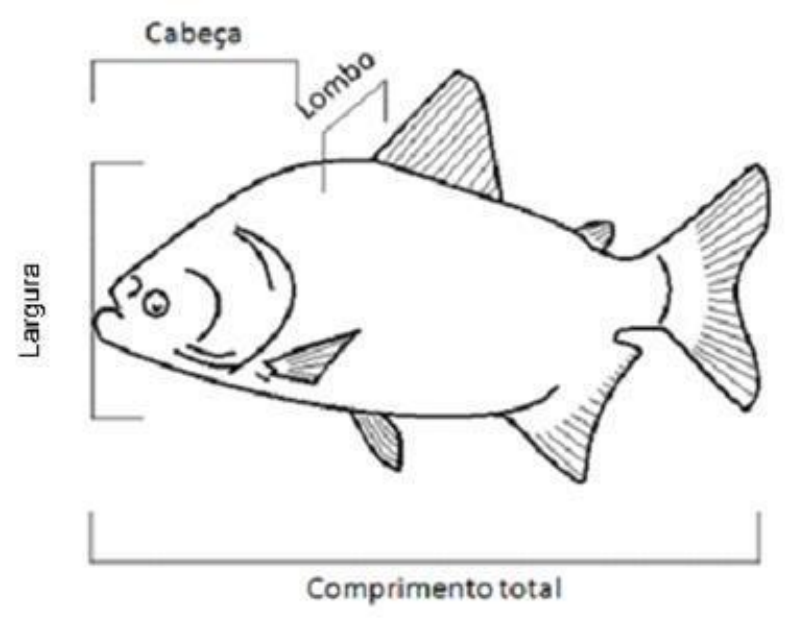

Figure 1: Measurements collected for the study on processing of males and females of tambaqui, reared in different stocking densities.

The fishs were measured for the whole weight, fillet weight, residual weight (whole animal weight minus fillet weight), fillet weight and yield (fillet weight divided by whole animal weight) (Figure 2). Each animal was considered a 
sampling unit, totaling 164 repetitions (77 males and 87 females).

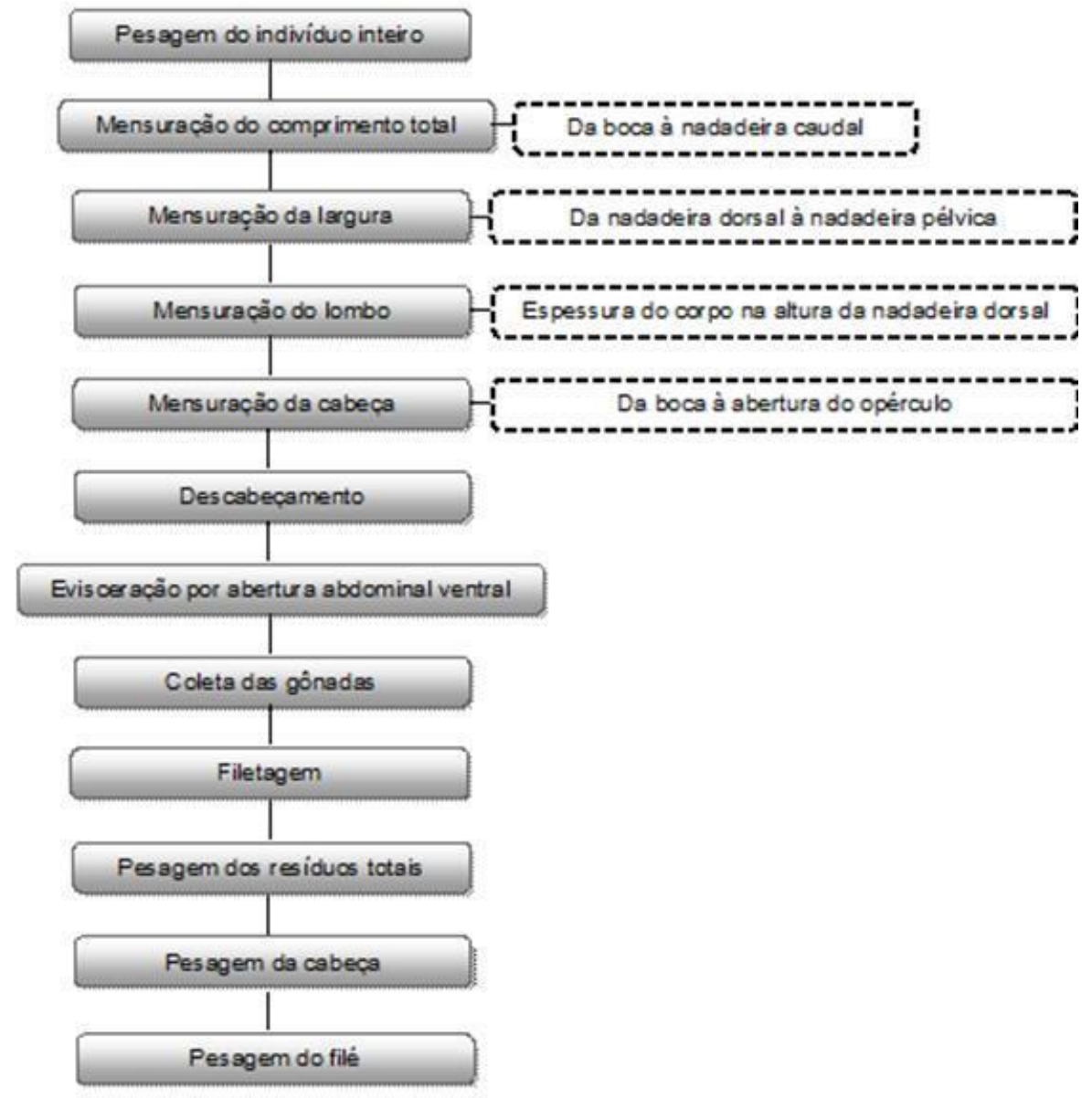

Figure 2: Tambaqui processing flowchart.

The gonads were removed and fixed in 10\% formalin (Vazzoler, 1996), later processed in paraffin, sectioned in 8 $\mu \mathrm{m}$ cuts, and stained by HematoxylinEosin (H-E). Next, the histological analyses were performed. Sex was identified under light microscope with 400 $\mathrm{X}$.

The analyses to determine the centesimal composition were: moisture and total lipids (Pregnolatto \& Pregnolatto, 1985), crude protein (Johnson \& Ulrich,
1974) and ash (Pregnolatto \& Pregnolatto, 1985; Winters \&Tennyson, 2006).

The experimental design used completely randomized blocks in $2 \times 2$ factorial scheme, where the first factor considered was the sex (male and female) and the second factor was the stocking density of the rearing system (4 or 6 tons per ha). Data normality was analyzed for all dependent variables. As it showed no normal distribution, the variable "loin" was transformed to cosine. Due to lipid data 
Mesquita et al., Revista Brasileira de Higiene e Sanidade Animal (v.12, n.2) p. 146 -155 abr - jun (2018)

distribution and the fact that protein behavior was not in a normal way, the variance analysis for non-parametric means was carried out by the KruskalWallis test.

We used a mixed model with fixed effects, rearing systems and their interactions, and the random residual effects and fish grouped by the sex, using the mixed procedure of the SAS statistical program, version 9.4. When differences occurred, the means were compared by the means feature. We used the akaike information criterion (AIC) to determine the model that best represented the data. The interaction between sex and rearing

Table 1: Correlation between the variables analyzed of tambaqui cultivated in different stocking densities.

\begin{tabular}{|l|l|l|l|}
\hline Variable & Variable & Yield & P \\
\hline Length & Width & 0.73 & $<.0001$ \\
\hline Length & Head & 0.68 & $<.0001$ \\
\hline Length & Loin & 0.55 & $<.0001$ \\
\hline Length & Initial weight & 0.79 & $<.0001$ \\
\hline Length & Fillet yield & 0.60 & $<.0001$ \\
\hline Length & Residual weight & 0.63 & $<.0001$ \\
\hline Length & Head weight & 0.62 & $<.0001$ \\
\hline & & & \\
\hline Width & Head & 0.56 & $<.0001$ \\
\hline Width & Loin & 0.62 & $<.0001$ \\
\hline Width & Initial weight & 0.92 & $<.00001$ \\
\hline Width & Fillet weight & 0.75 & \\
\hline Width & & & \\
\hline
\end{tabular}


Mesquita et al., Revista Brasileira de Higiene e Sanidade Animal (v.12, n.2) p. 146 -155 abr - jun (2018)

\begin{tabular}{|c|c|c|c|}
\hline Width & Head weight & 0.76 & $<.0001$ \\
\hline Head & Loin & 0.41 & $<.0001$ \\
\hline Head & Initial weight & 0.56 & $<.0001$ \\
\hline Head & Fillet weight & 0.28 & 0.0022 \\
\hline Head & Residual weight & 0.53 & $<.0001$ \\
\hline Head & Head weight & 0.58 & $<.0001$ \\
\hline Head & Fillet yield & -0.40 & $<.0001$ \\
\hline Loin & Initial weight & 0.67 & $<.0001$ \\
\hline Loin & Fillet weight & 0.52 & $<.0001$ \\
\hline Loin & Residual weight & 0.54 & $<.0001$ \\
\hline Loin & Head weight & 0.58 & $<.0001$ \\
\hline Initial weight & Fillet weight & 0.84 & $<.0001$ \\
\hline Initial weight & Residual weight & 0.76 & $<.0001$ \\
\hline Initial weight & Head weight & 0.78 & $<.0001$ \\
\hline Moisture & ash & -0.77 & $<.0001$ \\
\hline Ash & Lipids & -0.32 & 0.0009 \\
\hline Lipids & Protein & 0.30 & 0.0013 \\
\hline
\end{tabular}

Fish with large heads in relation to the body usually present lower yield at filleting. The relation between head size with yield is an important factor for the productive sector to select matrices with smaller head in relation to the body for genetic improvement of species and increased productivity (Galvão et al., 2010).

The yield of tambaqui fillet is similar to that of other Characidae species, like pacu (Piaractus mesopotamicus), 
ranging from 45.12 to $51.60 \%$ (Bittencourt et al., 2010).

Data on fish composition varied greatly according to extrinsic (rearing system) and intrinsic (sex) characteristics. The literature reports different data levels for contents of moisture, protein, lipids and

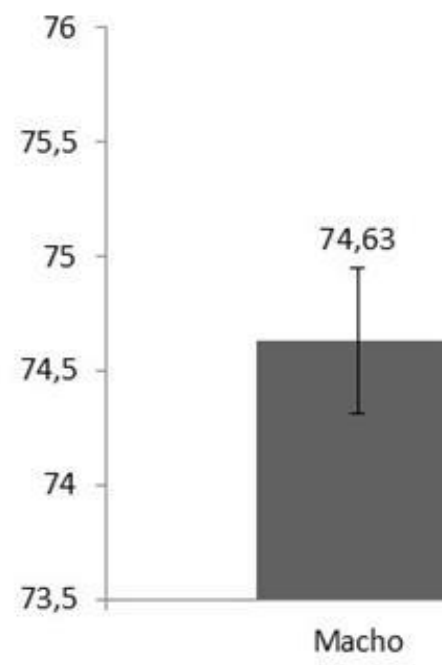

ash between males and females of some fish species (Goes et al., 2015; Mafra et al., 2015), affecting product standardization directly.

In our study, we found difference for the moisture content of fillets between males and females (Figure 3).

Figure 3: Difference between the average moisture content of fillets for males and females of tambaqui reared in different stocking densities.

Overall, fish muscle contains 60$85 \%$ of moisture and $1-5 \%$ of ash (Macedo - Viegas et al., 2000; Santos et al., 2001; Reidel et al., 2010). The correlation between moisture and lipid content is inversely proportional, as the lipid content is the most variable centesimal feature, ranging from $0.84 \%$ in lizardfish (Synodus intermedius) (Santos et al., 2001) to $13 \%$ in jundiá (Rhamdia quelen) (Reidel et al., 2010). The knowledge of such parameter studied is important for conservation of frozen fish once meat with high lipid levels undergo changes due to lipid oxidation.

Regarding stocking density of the production system, tambaqui grown in less dense systems are larger, featuring lower moisture content and higher ash and protein contents in the fillet (Table 2). Greater density can change fish behavior and reduce feed conversion, causing mortality and reducing growth (Montero et al., 1999).

Fish reared in lower density have higher growth rates (Silva \& Fujimoto, 
Mesquita et al., Revista Brasileira de Higiene e Sanidade Animal (v.12, n.2) p. 146 -155 abr - jun (2018)

2015) and high survival rate; however, lower yield per area (Gomes et al., 2000). High stocking densities result in greater productivity per area; however, fish display lower growth rate (El-Sayed, 2002). Thus, redistribution of animals in larger tanks is a recommended management practice (Souza et al., 2016).

Table 2: The average width of the whole tambaqui, moisture content, ash content and protein content of tambaqui fillet reared in different stocking densities

\begin{tabular}{llll}
\hline Variable & \multicolumn{2}{l}{ Rearing system } & P* \\
\cline { 2 - 3 } & 4 tonlha & 6 tonlha & \\
\hline Width & $18.59 \pm 0.22^{\mathrm{a}}$ & $17.96 \pm 0.11^{\mathrm{b}}$ & 0.0058 \\
Moisture & $74.11 \pm 0.18^{\mathrm{b}}$ & $75.36 \pm 0.20^{\mathrm{a}}$ & $<.0001$ \\
Ash & $5.76 \pm 0.15^{\mathrm{a}}$ & $4.80 \pm 0.24^{\mathrm{b}}$ & $<.0001$ \\
Protein & $16.00 \pm 0.40^{\mathrm{a}}$ & $14.63 \pm 0.30^{\mathrm{b}}$ & 0.0089
\end{tabular}

*Probability between rearing systems. Different letters in the rows differ by the Tukey test $(\mathrm{P}<0.05)$

Stocking densities influence social behavior and may compromise the rearing system. Low stocking densities in other species, such as salmon (Salmo salar) favor the emergence of hierarchical, dominant and subordinate classes, in which the dominant class monopolizes the food and feeding areas, leading to different growth rates of individuals (Maclean \& Metcalfe, 2001). the productive chain of the species, since stocking density is critical for performance optimization, standardization in processing and marketing steps of the product.

The interaction of the sex with the rearing system shows that, in high densities, females present lower fillet yield than males. Conversely, males have a higher fillet yield than females in the same rearing system.

Therefore, studies are important for

Table 3: Fillet yield between sex and rearing systems.

\begin{tabular}{lll}
\hline Rearing systems & Sex & \\
\cline { 2 - 3 } & Male & Female \\
\hline 4 SR & $36.06 \pm 0.54^{\mathrm{b}}$ & $37.49 \pm 0.75^{\mathrm{a}}$ \\
$6 \mathrm{SR}$ & $36.04 \pm 0.55^{\mathrm{a}}$ & $34.55 \pm 0.59^{\mathrm{b}}$ \\
\hline
\end{tabular}

$*$ Different letters in different rows differ by the Tukey test $(\mathrm{p}<0.05)$ 
Mesquita et al., Revista Brasileira de Higiene e Sanidade Animal (v.12, n.2) p. 146 -155 abr - jun (2018)

Overall, viscera in finfish comprise around $11 \%$ of total weight (ContrerasGuzmán, 1994). However, due to the increased volume of gonads in jundiá, with the approach of the reproductive period, fish of both sexes have higher average weights (Reidel, et al., 2010). Yield values decrease during the rearing period, showing decreasing growth trends, possibly influenced by the reproductive cycle of animals.

Sexual maturity is one of the biological processes that most affect yield in intensive crops, as the energy for somatic growth is channeled into the production of gametes, reducing growth during the period of sexual maturity. To minimize problems, such as lack of standardization between the sexes, monosex populations have been reared in several species. For many species, this management is justified. This rearing system is recommended for the production of rainbow trout (Oncorhynchus mykiss) and tetra (Astyanax sp.), for example.

The literature reports differences in growth patterns between male and female adults of tambaqui showing sexual dimorphism in this species in adulthood (Mello et al., 2015). The understanding of these growth differences is important to create management strategies, suggesting the need for adjustments to technological procedures currently used.

\section{Conclusion}

Similar to other species, differences were found between sexes for centesimal aspects and yield, allowing to select features of interest, such as fillet moisture (with males showing less moisture than females), for rearing monosex populations.

Stocking density should be taken into consideration for the production of tambaqui, as fish grown in lower density systems are larger, feature lower moisture content and higher ash and protein contents in the fillet. In addition, the behavior of animals in inadequate stocking densities can compromise yield of batches.

The interaction of the sex with the rearing system shows that, under high stocking densities, females have lower fillet yield than males, while males have higher fillet yield than males in higher stocking densities. The knowledge of the interaction of the variables analyzed in this work requires the identification of the most interesting features for the market, as some features stand out when the sex of the animals and stocking densities are prioritized.

This study shows that the protocol used for tambaqui production needs to be reviewed. 
Some variables in the rearing system are still not well understood, such as differences between the sexes for carcass yield and growth rate in different

\section{References}

1.BARÇANTE, B., DE SOUSA, A. B.. Características zootécnicas e potenciais do tambaqui (Colossoma macropomum) para a piscicultura brasileira. PubVet, v. 9, p. 287$347,2015$.

2.BITTENCOURT, F., FEIDEN, A., SIGNOR, A. A., BOSCOLO, W. R., LORENZ, E. K., MALUF, M. L. F. Densidade de estocagem e parâmetros eritrocitários de pacus criados em tanques-rede. Revista Brasileira de Zootecnia, v. 39, n. 11, p. 2323-2329, 2010.

3.BORGES, B. A. A. Identificação de neomacho de Jundiá Rhamdia quelen (Quoy e Gaimard, 1824) através do teste de progênie. UFSC, Florianópolis, SC, 2015. 21p. (Trabalho de Conclusão de Curso) Universidade Federal de Santa Catarina, SC, 2015.

4.BRITO, M. J. M.. Uso de prebiótico para tilápia-do-nilo durante o período de inversão sexual. UFPB, Areia - PB, 2016. 30p. (Trabalho de Conclusão de Curso) Universidade Federal da Paraíba, PB, 2015.

\section{CONTRERAS-GUZMÁN, E. S. Bioquímica de pescados e derivados. FUNESP, 1994.}

DA SILVA, C. A., FUJIMOTO, R. Y. Rodrigo Yudi. Crescimento de tambaqui em resposta a densidade de estocagem em tanques-rede. Acta Amazonica, v. 45(3) p. 323 - 332, 2015.

6.EL- SAYED, A. M. Effects of stocking density and feeding levels on growth and feed efficiency of Nile tilapia (Oreochromis niloticus L.) fry. Aquaculture research, v. 33, n. 8, p. 621-626, 2002. stocking densities. Further studies are needed to focus on yield and centesimal features of interest in technological procedures.

7.GALVÃO, J. A., MARGEIRSSON, S., GARATE, C., VIĐARSSON, J. R., \& OETTERER, M. Traceability system in cod fishing. Food control, v. 21, n. 10, p. 13601366, 2010.

8.GOES, E. S. R; FEIDEN, A.; NEU, D. H.; GOES, M. D.; BOSCOLO, W. R.; SIGNOR, A.. Rendimentos do processamento e composição centesimal de filés do jundiá Rhamdia voulezi. Ciência Animal Brasileira, v. 16, n. 4, p. 481-490, 2015.

9.GOMES, L. C.; BALDISSEROTTO, B.; SENHORINI, J. A. Effect of stocking density on water quality, survival, and growth of larvae of the matrinxã, Brycon cephalus (Characidae), in ponds. Aquaculture, v. 183, n. 1-2, p. 73-81, 2000.

10.JOHNSON, C. M.; ULRICH, A. Analytycal methods. In.: SARRUGE, J. R.; HAAG, H. P. Análises químicas em plantas. Piracicaba: ESALQ/Departamento de Química. Setor nutrição mineral de plantas (modificado: quantidade de reagentes para preparo da mistura digestora), 1974. p.04-10.

11.MACEDO-VIEGAS, E. M.; SCORVO, C. M.; VIDOTTI. E, R. M.; SECCO, E. M. Efeito das classes de peso sobre a composição corporal e o rendimento de processamento de matrinxã (Brycon cephalus). Acta Scientiarum. Animal Sciences, v. 22, n. 1, p. 725-728, 2000.

12.MACLEAN, A.; METCALFE, N. B. Social status, access to food, and compensatory growth in juvenile Atlantic salmon. Journal of Fish Biology, v. 58, n. 5, p. 1331-1346, 2001. 
Mesquita et al., Revista Brasileira de Higiene e Sanidade Animal (v.12, n.2) p. 146 -155 abr - jun (2018)

13.MAFRA, D. P., DRESCH, R. T., COSTA, L. H. C., COSTA, C. S., KLEIN, S., DIEMER, O. Características morfométricas, rendimento corporal e composição química da piranha. Agrarian, v. 9, n. 34, p. 383-389, 2016.

14.MELLO, F. D., OLIVEIRA, C. A., RIBEIRO, R. P., RESENDE, E. K., POVH, J. A., FORNARI, D. C., STREIT JR, D. Growth curve by Gompertz nonlinear regression model in female and males in tambaqui (Colossoma macropomum). Anais da Academia Brasileira de Ciências, v. 87, n. 4, p. 23092315, 2015.

15.MONTERO, D.; IZQUIERDO, M.S.; TORT, L.; ROBAINA, L. VERGARA, J.M. High stocking density produces crowding stress altering some physiological and biochemical parameters in gilthead seabream, Sparus aurata, juveniles. Fish Physiology and Biochemistry, v. 20, n. 1, p. 53-60, 1999.

16.PREGNOLATTO, W.; PREGNOLATTO, N. P. (Coord.).Normas analíticas do Instituto Adolfo Lutz: métodos químicos e físicos para análise de alimentos. 3 ed. São Paulo: Instituto Adolfo Lutz, p.27-28. 1985.

17.RAMOS, Fabrício Menezes et al. Peixes ornamentais do rio xingu: manutenção e reprodução do Acari zebra Hypancistrus zebra Isbrücker \& Nijssen, 1991 (Siluriformes, Loricariidae) em cativeiro. UFPR, Belém, PR, 2016. 98p. (Tese de Doutorado) Universidade Federal do Pará, PR, 2016.

18.REIDEL, A.; ROMAGOSA, E.; FEIDEN, A.; BOSCOLO, W, R; COLDEBELLA, A; SIGNOR, A, A. Rendimento corporal e composição química de jundiás alimentados com diferentes níveis de proteína e energia na dieta, criados em tanques-rede. Revista Brasileira de Zootecnia, v. 39, n. 2, p. 233240, 2010.

19.SANTOS, A. B.; MELO, J. F. B.; LOPES, P. R. S. MALGARIM, M, B. Composição química e rendimento do filé da traíra (Hoplias malabaricus). Revista da FZVA, v. 8, n. 1, 2001.
20.SOUSA, R. G. C., PIÑEYRO, J. I. G., CARDOSO, N. A., ANDRADE, J. E., SILVA, J. G., BARBOSA, H. T. B.. Stocking density and its effects to the zootechnical development of young tambaqui in an intensive production system Densidade de estocagem e seus efeitos sobre o desenvolvimento zootécnico de juvenis de tambaqui em sistema intensivo de produção. Acta of Fisheries and Aquatic Resources, v. 4, n. 1, p. 80-92, 2016.

21.VAZZOLER, A. E. A. Biologia da reprodução de peixes teleósteos: teoria e prática. Maringá: Eduem, v. 169, 1996.

22.VILLACORTA-CORREA, M. A.; SAINTPAUL, U. Structural indexes and sexual maturity of tambaqui Colossoma macropomum (Cuvier, 1818) (Characiformes: Characidae) in Central Amazon, Brazil. Revista brasileira de biologia, v. 59, n. 4, p. 637-652, 1999.

23.WINTERS, S.; TENNYSON, J. Fish and other marine products - a isho fsea food. In.: HORWITZ, W. (Ed.). Association of official analytical chemists (AOAC).Official methods of analysis of AOAC international.18th ed. Gaithersburg, Chap. 35.p.8. 2006. 